HELIA, 30, Nr. 46, p.p. 1-12, (2007)

UDC 633.854.78:631.524.86

DOI: 10.2298/HEL0746001V

\title{
IMPROVEMENT OF Sclerotinia sclerotiorum HEAD ROT RESISTANCE IN SUNFLOWER BY RECURRENT SELECTION OF A RESTORER POPULATION
}

\author{
Vear, F. ${ }^{*}$, Serre, F., Roche, S., Walser, P. and Tourvieille de Labrouhe, D. \\ INRA, UMR INRA-Université Blaise Pascal "Amélioration et Santé des Plantes", \\ Domaine de Crouelle, 234, Ave du Brezet, 63000 Clermont Ferrand, France
}

Received: March 10, 2007

Accepted: June 25, 2007

SUMMARY

\begin{abstract}
Recurrent selection for resistance to Sclerotinia head rot was carried out for 15 cycles on a restorer sunflower population created in 1978. For the first 3 cycles a test measuring rate of extension of mycelium on the back of capitula was used; from the fourth cycle onwards, it was combined with a test based on ascospore infections, which repeat more closely natural infections. An $80 \%$ reduction in diseased area was obtained in 4 cycles, with the first test, thereafter the population remained stable and homogeneous for this character. In 12 cycles the latency index (measure of incubation period) of the ascospore test doubled, and the best relation with cycle was a simple regression, with a significant slope, indicating that further improvements should be possible. The hybrids made with the first, sixth and fifteenth generations of the population showed a halving of percentage attack in the field and hybrids with some of the best lines bred from several cycles presented even greater levels of resistance. This population is available to sunflower breeders and scientists.
\end{abstract}

Key words: ascospores, mycelium, hybrids, quantitative resistance, breeding

\section{INTRODUCTION}

Head rot caused by Sclerotinia sclerotiorum was one of the first diseases to become important when sunflowers developed as a world wide crop, following the production of hybrids. Infections occur if there is rainfall during flowering. Epidemics have been reported in many countries including Argentina (Huguet and Heiland, 2000), China (Liu and Li, 1988), France (Lamarque, 1976), Iran (Ali-Agha, 1974), South Africa (Philips, 1989) and the USA (Gulya, 1996). Since S. sclerotiorum can attack most plants except Poaceae, it adapts to all sorts of plant genotypes, and no complete resistance is known within cultivated sunflower, or even the Helianthus

* Corresponding author: Phone: 33.4.73.62.43.06; Fax: 33.4.73.62.44.353;

e-mail: vear@clermont.inra.fr 
genus. However, considerable differences in reaction do exist (Vear and Tourvieille, 1988), and the advantage of this quantitative type of resistance is that appears not to vary according to pathogenic isolate (Vear et al., 2004).

A recurrent selection programme was started in 1978 (Vear and Tourvieille, 1984), with the objective of combining resistance factors from many different cultivated sunflower genotypes, using one and then two resistance tests on individual plants in each cycle. Sixteen cycles have now been completed. This paper presents the gain obtained, measured not only by tests but also on hybrids under semi-natural attack, suggesting that this population now contains a good combination of resistance genes which may be useful in modern sunflower breeding programmes.

\section{MATERIALS AND METHODS}

\section{Sunflower population}

A population was created in 1978 by intercrossing 40 sunflower genotypes, inbred lines such as "PAC1"and "PAC2" and $\mathrm{F}_{3}-\mathrm{F}_{6}$ progenies, known to have good levels of resistance to Sclerotinia head rot. These included material derived from "HA61", "Yougo.2.2" (male parent of the genic hybrid INRA 4701), "AD66", "RHA 274", "RHA 271", "RHA 296", "ZN41" (male parent of the 3-way hybrid "Luciole"), restorers derived by P.Leclercq from H.petiolaris ("BC251", "BZA1" and others), lines derived from VNIIMK 8883 and lines with genic male sterility derived from a cross between the open pollinated varieties "Armavir 9345" and "Nain Noir".

\section{Recurrent selection programme}

A recurrent selection programme for Sclerotinia sclerotiorum headrot resistance was carried out, each cycle consisting of one generation of interpollination between chosen genotypes/plants, in isolated plots (or under insect-proof mesh cages containing bees), followed by one generation of self pollination (under greaseproof paper bags) and at the same time, a Sclerotinia resistance test, of a sample of 200-400 plants. For the interpollinations, equal quantities of seed of the chosen plants were mixed and sown at two dates to favorise crosses between early and late genotypes. Harvest was in bulk and the 400 plants tested at the following generation constituted a random sample. Self pollination was obtained by covering each capitulum with a grease-proof paper bag just before flowering. The Sclerotinia resistance tests were applied at and after flowering and the best $20 \%$ of plants were used to form the following generation. Although reaction to Sclerotinia was the main selection criterion, excessively tall, late, self-sterile or low oil $(>35 \%)$ plants were eliminated and plants with resistance to downy mildew races 100/304 were given priority so that the population is now resistant to race 304 (and in 2004 had a mean oil content of 43.6). The population has been bred with the objective of giving restorer lines with recessive branching. 
For the first two cycles, only one test using Sclerotinia mycelium was applied and the intercrossing generation was made in a winter nursery. From the third cycle onwards, a test using ascospores was introduced. For this, the main stem of each plant was cut above the first pair of true leaves, so that 2 axillary stems developed, each producing a capitulum with about the same flowering date. One was inoculated with ascospores in the field, while the other was harvested after flowering and inoculated with mycelium in a growth chamber (see Figure 1). The intercrossing generation was carried out as in the first cycles. The two generations of each cycle were made under summer conditions in France, over two years. From the third to the seventh cycle ascospore tests were carried out in the field, without irrigation but the level of infection became so low that selection was no longer possible. Following cycles were therefore carried out under netting cages, as for interpollination, but with external irrigation which creates a fine mist very favourable for Sclerotinia. Fifteen cycles have now been completed and a sixteenth intercrossing has been made.

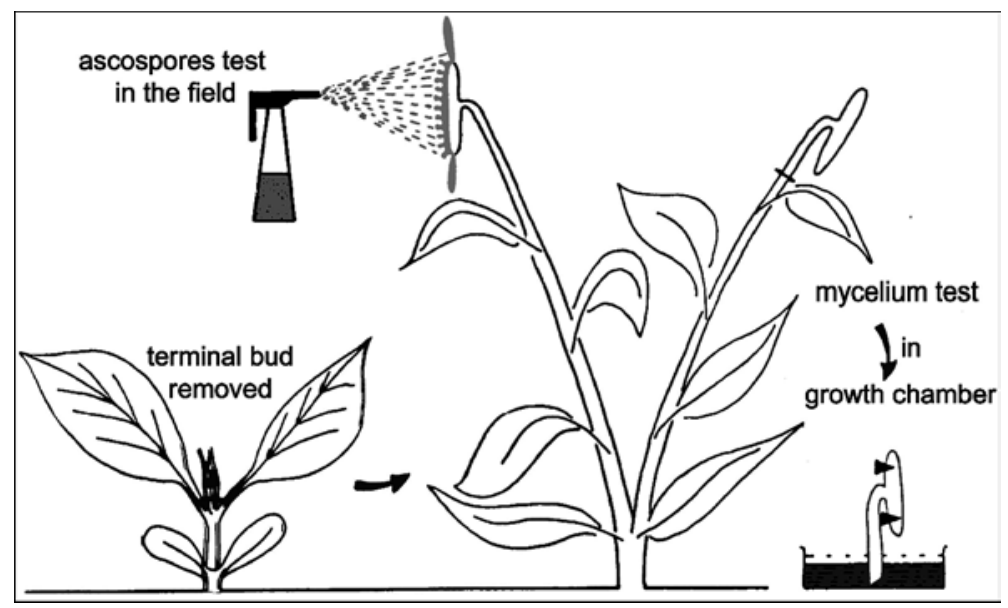

Figure 1: Diagram of the method used to produce sunflower plants with two capitula on which the two Sclerotinia resistance tests were carried out simultaneously

In 2003, when the fifteenth interpollination was made, samples of the first and sixth generations were also grown under netting cages and in each of the 3 cages 4 cytoplasmic male sterile lines (SD very good resistance, VHQ good resistance, FU good resistance, GB poor resistance) were grown to produce hybrids with the 3 different cycles of the population. These 4 hybrids were then observed under semi-natural attack (irrigation during flowering to give favourable conditions) in 2004 and 2005 to provide a judgement of the gain in overall resistance.

Samples of cycle 16 of this population are available (to breeders and scientists) from the first author.

\section{Resistance tests}

Mycelium test, on capitula in a growth chamber. This test was described by Vear and Guillaumin (1977) and Castaño et al. (1993). It determines the rate of 
mycelial extension on the dorsal surface of maturing capitula, 3 days after placing on them malt agar ex-plants containing young Sclerotinia mycelium. The stems of the capitula soaked in water and they were maintained at $100 \%$ relative humidity at $18^{\circ} \mathrm{C}$. Since the diseased area varied according to Sclerotinia aggressiveness and mycelium age, results are expressed as percentages of the diseased area on capitula of a control variety, "Remil", infected at the same time.

\section{Ascospore test, in field or cage}

This test was described by Tourvieille and Vear (1984) and Castaño et al. (1993). During pollen production, capitula were sprayed with an ascosopre suspension and maintained under the paper bags used for selfing. To cover different flowering dates, infections were made twice a week for 3 to 4 weeks, generally in July. Symptoms observed were the first appearance of rotted spots on the dorsal surface of capitula, two to 10 weeks after infection. The population was judged by the overall percentage of plants with symptoms and individual plants by the presence of symptoms and the delay in symptom appearance. This was taken as days in the third cycle but from the fourth cycle onwards, it was expressed as a latency index, obtained by dividing the number of days before symptom appearance for each plant by the mean delay of two controls, SD, resistance and GU, susceptible, infected on the same day as the plant (multiplied by 100). The more resistant plants thus had a higher latency index than the more susceptible. All the plants remaining without symptoms were harvested each year between September 10-15 $5^{\text {th }}$, the normal date for maturity.

\section{Semi natural attack}

This type of trial was first described by Vear and Tourvieille (1987) and has been used for many years to determine Sclerotinia reaction in official trials in France. Hybrids are sown as in normal yield trials, but in fields infected with $S$. sclerotiorum sclerotia. Complete cover irrigation is provided before flowering to favourise ascospore production and then the capitula are maintained wet throughout flowering to permit infection whatever the flowering date. Irrigations are provided after flowering to obtain slow maturation. Head rot symptoms are observed at or after physiological maturity. The percentages of plants with symptoms are compared with those of control varieties sown at three dates to take into account environmental effects during flowering and maturation, in particular temperatures and the quantity of inoculum present in the field.

\section{RESULTS AND DISCUSSION}

A summary of data for the two tests at each cycle and the means of plants chosen for the following cycle are presented in Table 1 . 


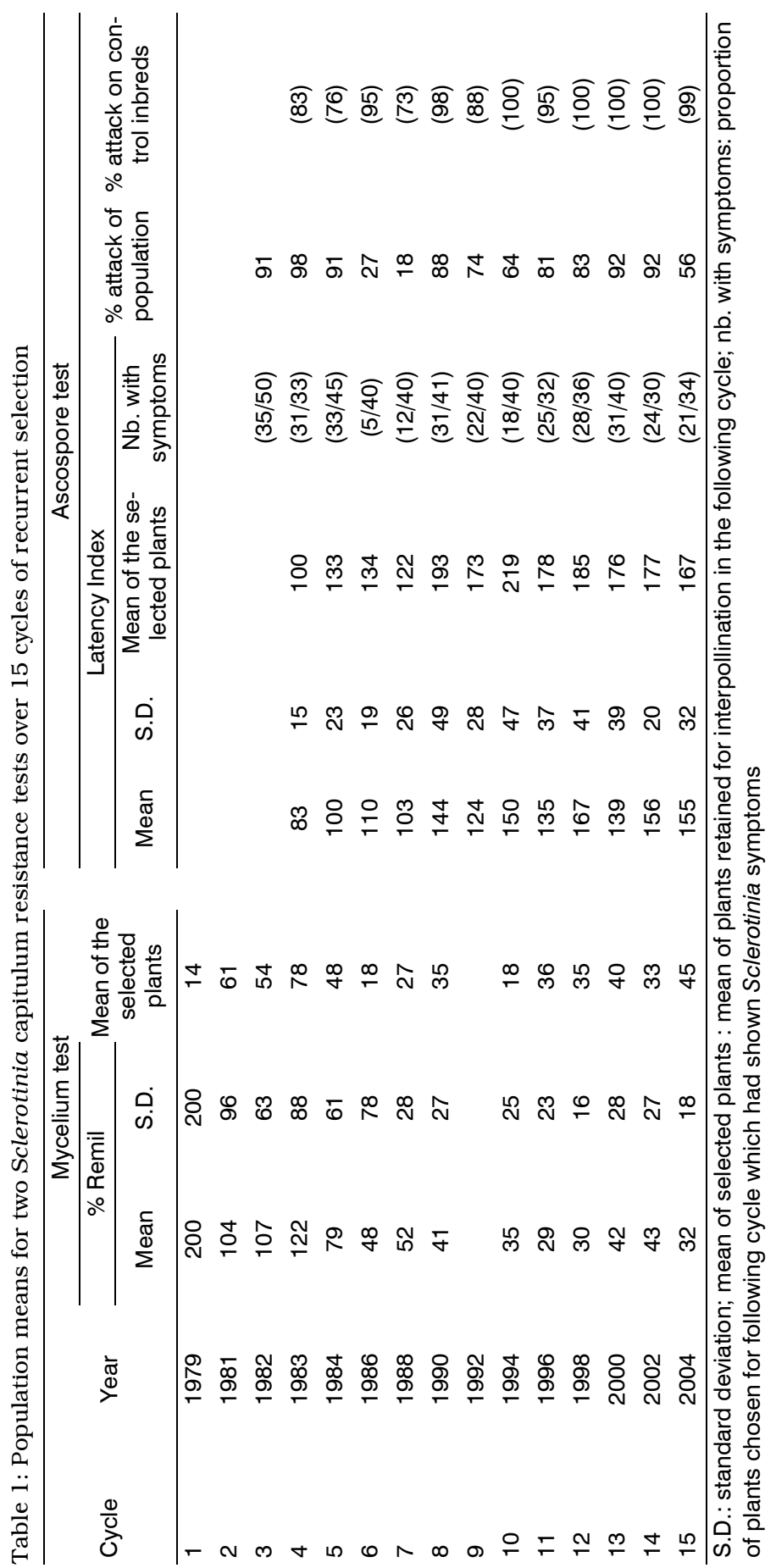


For the mycelium test, the strong selection pressure in the first cycle reduced the population mean by half in the second cycle. Thereafter the reduction in diseased area was slower, perhaps because choice of plants according to the results of the ascospore test meant that those with the best reaction to the mycelium test were not always retained. However, it may also be noted that the mean of one cycle does not exactly follow the mean of the plants chosen to make up the population for that cycle. The standard deviation dropped until cycle 7 , when it was about half the population mean. The best relation between population mean and cycle is a second degree regression $\left(\mathrm{y}=197.2-30.3 \mathrm{x}+1.35 \mathrm{x}^{2}, \mathrm{p}<0.001 ; \mathrm{R}^{2}=85.6 \%\right)$, shown in Figure 2a. This indicates that there was a significant gain in resistance for the first 11 cycles (reducing rate of mycelium extension by $85 \%$ ) but that since then there has been no change. The population would appear to be homogeneous, perhaps homozygous, for this resistance character.

The ascospore test in the third cycle was not comparable with the others since no latency index was calculated. However, percentage attack was similar to that in the fourth cycle. Although most of the plants forming the following cycles were chosen according to their latency indices (70-90\% attack), the mean level of attack dropped rapidly to $18 \%$ after 4 cycles, although the controls showed more than $70 \%$ infection. From cycle 8 onwards, the plants for test were grown under netting cages with external irrigation, giving a fine mist very favourable for Sclerotinia attack (Tourvieille et al., 1986). The mean percentage of plants showing symptoms increased again to $60-90 \%$, except in the last cycle when only $56 \%$ of plants showed symptoms. Although there was little variation for the controls, differences in the population were partly due to differences in environmental conditions between years, in particular, cooler temperatures $\left(20-25^{\circ} \mathrm{C}\right.$ compared with $\left.25-35^{\circ} \mathrm{C}\right)$ gave more rapid appearance of symptoms and thus fewer plants still healthy at harvest on September 10-15 ${ }^{\text {th }}$ (Serre et al., 2004).

Environmental conditions also affected the latency index. Although this index is a comparison with control lines infected at the same time as the population, when symptom appearance was very rapid, (control mean 20-25 days), the latency index could exceed 200 (symptoms after 50-60 days) whereas with a mean delay for the controls of 35-40 days, the latency index could not exceed 180-150. It may be for this reason that increases in latency index were irregular, but they were highly significant, with a simple regression of latency index on cycle of $y=70.11+6.36 \mathrm{x}$, $\mathrm{p}=0.0002 ; \mathrm{R}^{2}: 75.6 \%$ ) (Figure $2 \mathrm{~b}$ ). Mean gain per cycle was $6.5 \%$, with almost doubling of latency index in 8 cycles $(* 1.87)$. A second degree regression was calculated but was only $90 \%$ significant, the simple regression gave the best fit of all the data. Thus, although there appears to be a rounding off of the increase in latency index in the last selection cycles, further improvements still appear possible, the population is probably not completely homogeneous for this character.

The hybrids produced in 2003 with cycles 1,6 and 15 were observed in 2004 and 2005 under conditions of semi-natural attack to determine what gain for 


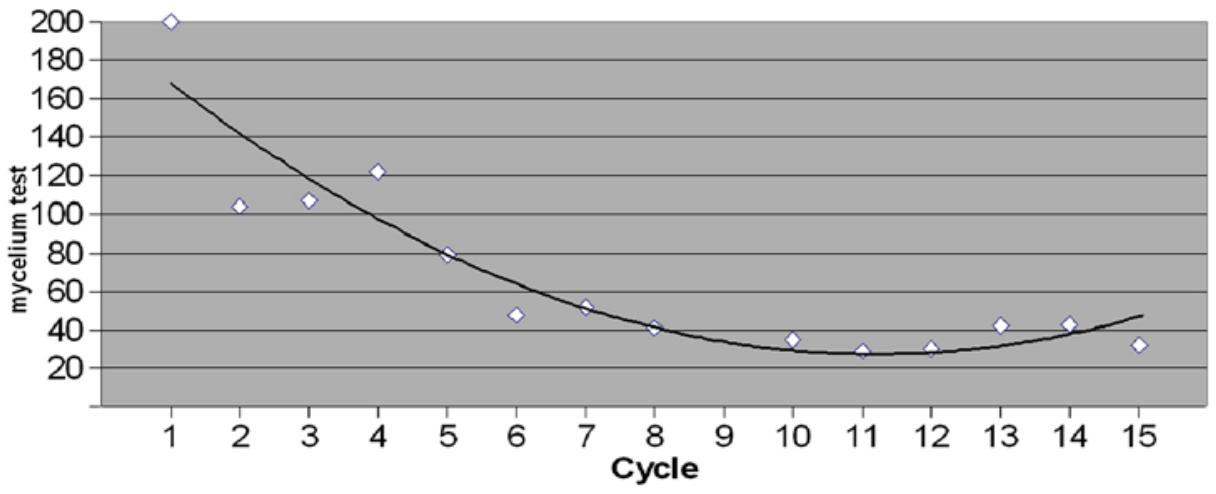

Figure 2a:Changes in the reaction of a sunflower population under recurrent selection for Sclerotinia sclerotiorum head rot resistance over 15 cycles. a) Mycelium test

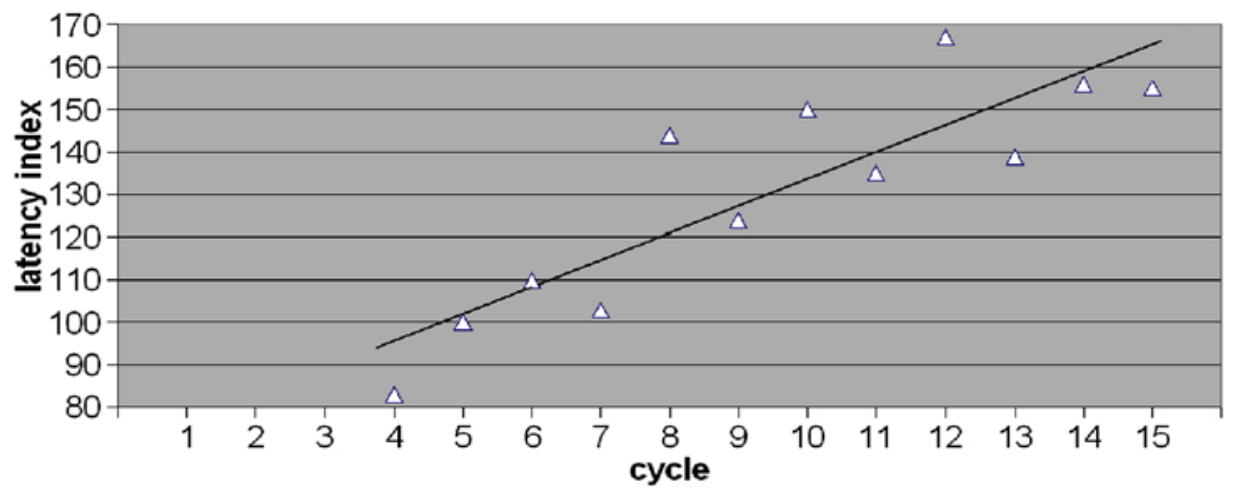

Figure 2b:Changes in the reaction of a sunflower population under recurrent selection for Sclerotinia sclerotiorum head rot resistance over 15 cycles. b) Ascospore test (latency index)

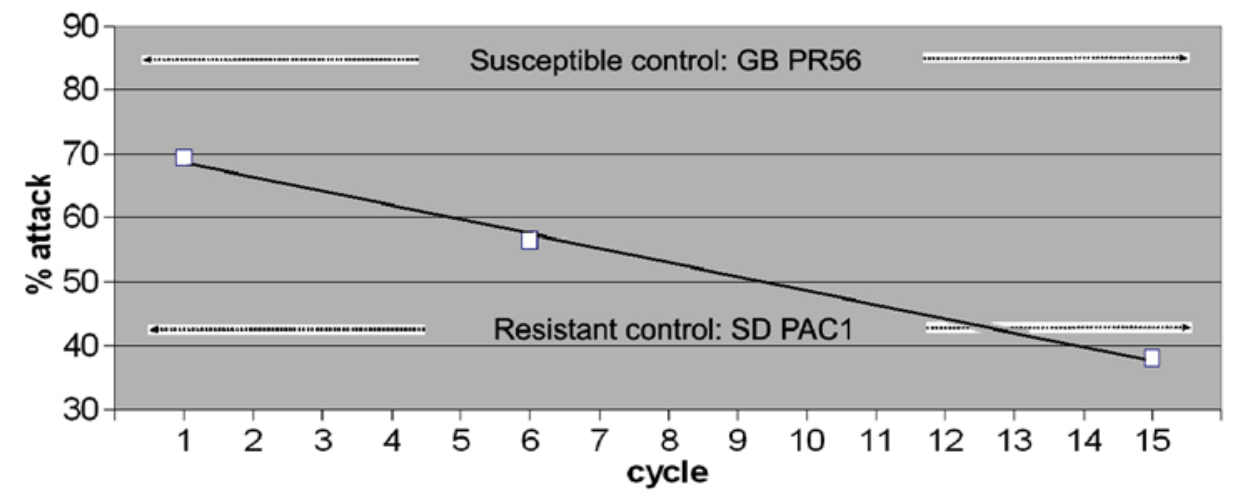

Figure 2c:Changes in the reaction of a sunflower population under recurrent selection for Sclerotinia sclerotiorum head rot resistance over 15 cycles. c) Semi natural attack on hybrids made with 3 generations of the population. 
hybrids grown under field conditions the selection by the two tests had produced. Results are given in Table 2. Data are percentage attack corrected for flowering date by comparison with control hybrids sown at 3 dates. The mean attack in 2004 was much lower (40\%) than in 2005 (68\%), but the results for each hybrid in the two years were significantly correlated $(r=0.72, p=0.001)$. In both years, the first cycle hybrids appeared slightly less susceptible than the susceptible control GB $\times$ PR56. The $15^{\text {th }}$ cycle hybrids showed only just over half the attack observed on the first cycle hybrids (means 38\% and 69\% attack, respectively). Although there are only 3 points on the graph (Figure 2c), the linear relation between the mean attack of hybrids and cycle number is significant ( $y=70.83-2.21 x ; R^{2}: 99.6 \%$, p: 0.042), suggesting that, like latency index, further improvements in resistance are possible by selection of the population. These results confirm that the Sclerotinia resistance tests by mycelium and, more particularly, ascospore infections are efficient in breeding for increased resistance. From the regressions presented in Table 2, for the first 3 cycles, a reduction of $39 \%$ in diseased area from the mycelium test gave a $11 \%$ reduction in field attack. Then, for the 12 cycles of ascospore test (with some effect of the mycelium test at first), the increase of $86 \%$ in latency index gave a $64 \%$ reduction in field attack.

Table 2: Sclerotinia head rot attack of hybrids made with cycles 1, 6 and 15 of the recurrent selection population and of some controls, observed under semi-natural attack in 2004 and 2005.

\begin{tabular}{lcccc}
\hline Hybrid & 2004 & 2005 & Mean & $\begin{array}{c}\text { Mean for popu- } \\
\text { lation cycle }\end{array}$ \\
\hline SD $\times$ ISCM (pop cycle 1) & 43.1 & 81.9 & 62.5 & \\
FU $\times$ ISCM (pop cycle 1) & 54.2 & 92.4 & 73.3 & \\
VHQ $\times$ ISCM (pop cycle 1) & 45.7 & 88.9 & 67.3 & $69.38 \%$ \\
GB $\times$ ISCM (pop cycle 1) & 55.2 & 93.6 & 74.4 & \\
\hline SD $\times$ ISCMR6 (pop cycle 6) & 44.7 & 70.9 & 57.8 & \\
FU $\times$ ISCMR6 (pop cycle 6) & 45.2 & 65.7 & 55.5 & \\
VHQ $\times$ ISCMR6 (pop cycle 6) & 43.1 & 64.0 & 53.6 & $56.38 \%$ \\
GB $\times$ ISCMR6 (pop cycle 6) & 57.8 & 59.3 & 58.6 & \\
\hline SD $\times$ ISCMR15 (pop cycle 15) & 18.9 & 50.0 & 34.5 & \\
FU $\times$ ISCMR15 (pop cycle 15) & 28.9 & 52.9 & 40.9 & \\
VHQ $\times$ ISCMR15 (pop cycle 15) & 21.0 & 32.6 & 26.8 & $38.08 \%$ \\
GB $\times$ ISCMR15 (pop cycle 15) & 42.1 & 58.1 & 50.1 & \\
\hline SD $\times$ PSC8 (from cycle 5) & 18.4 & 59.9 & 39.2 & $(47.99 \%)$ \\
VHQ $\times$ PSC8 (from cycle 5) & 32.6 & 56.4 & 44.5 & \\
GB $\times$ PSC8 (from cycle5) & 25.8 & 80.2 & 53.0 & \\
\hline SD $\times$ PAC1 & 28.9 & 56.4 & 42.6 & \\
\hline GB $\times$ PR56 & 73.6 & 100.0 & 86.8 & \\
\hline Resuls &
\end{tabular}

Results are percent attack, corrected for the effects of flowering date by comparison with control hybrids sown at three dates. 
Table 2 also shows the observations on some hybrids made with one of the best lines developed from cycle 5 of the population (PSC8). Its hybrid with the female line SD is slightly better than that obtained with the line PAC1, an original constituent of the population. The hybrid SD $\times$ PAC1 was for many years the resistant control in French official trials. The mean of the 3 hybrids made with PSC8, corrected for the lack of the hybrid with the female FU, was slightly better than the population mean for the sixth cycle, indicating that inbred lines with better levels of resistance than the population mean can be developed. This was confirmed with lines bred from later cycles, in other trials in the same fields in 2004 and 2005. Three lines (PSX2, PSX3, PSX6) bred from cycle 8, crossed with VHQ, showed 26.7\%, 36.3\% and $43.8 \%$ attack in 2004 , respectively, intermediate between the resistance levels of the hybrids made with cycles 6 and 15 of the population $(43.1 \%$ and $21.0 \%$, respectively). In the same year, a line (PSX4) selected from cycle 9, crossed with VHQ, showed $32 \%$ attack. In 2005, 3 hybrids between VHQ and lines developed from cycle 13 showed from less attack than VHQ $\times$ population cycle 15: $21.8 \%$, $29.5 \%$ and $31.8 \%$ compared with $32.6 \%$ (Table 1 ). The same year, hybrids with the best lines from cycle 14 showed similar levels of attack: $22.7 \%, 27.3 \%$ and $34.3 \%$.

\section{CONCLUSIONS}

Over 15 cycles general Sclerotinia head rot resistance has been significantly improved. The mycelium test, measuring the rate of mycelium extension during three days on the dorsal surface of the capitulum is a relatively simple character, which may thus be controlled by relatively few genes. This may be why it there was quite rapid improvement and then apparent fixation of the character. In contrast, responses to the ascospore tests, which depend on spore germination, tissue infection and mycelial installation in the rapidly changing tissues of the sunflower capitulum during and after flowering may be under much more complex control, explaining the variability which still appears to exist in the population after 12 cycles selecting with this test. For the field resistance of hybrids, the two mechanisms probably play a role and although the number of generations studied was small, the results suggest that it should be possible to obtain further improvements by selection among the most recent form of the population. Nevertheless, after 15 cycles, it appears useful to introduce new origins, if possible new forms, of resistance, to make further significant gains. This could help to forecast what level of resistance to Sclerotinia head rot it may be possible to attain in cultivated sunflowers.

This quantitative nature of Sclerotinia resistance has been confirmed by studies of QTL. For example Bert et al. $(2002,2004)$ showed that, according to cross, 4 or 5 QTL, different according to genotypes studied, may be involved. It is for this reason that it is most important to include genotypes with good combinations of resist- 
ance factors in breeding programmes. We feel that this population may be of use in this respect.

\section{ACKNOWLEDGEMENTS}

We would like to thank Dr. F. Castaño for critical reading of the manuscript and the Spanish version of the summary. We thank the personnel of the INRA farm at Clermont-Ferrand for their help with Sclerotinia resistance tests and trials.

\section{REFERENCES}

Ale-Agha, N., 1974. Etude du Sclerotinia sclerotiorum (Lib) de Bary. en Iran. Annales de Phytopathologie 6:385-393.

Bert, P-F., Jouan, I., Tourvieille de Labrouhe, D., Serre, F., Nicolas, P., Vear, F., 2002. Comparative genetic analysis of quantitative traits in sunflower (Helianthus annuus L.). 1. QTL involved in resistance to Sclerotinia sclerotiorum and Diaporthe helianthi. Theor.Appl.Genet. 105:985-993.

Bert, P-F., Deschamp-Guillaume, G., Serre, F., Jouan, I., Tourvieille de Labrouhe, D., Nicolas, P. and Vear, F., 2004. Comparative genetic analysis of quantitative traits in sunflower (Helianthus annuus L.) 3. Characterisation of QTL involved in resistance to Sclerotinia sclerotiorum and Phoma macdonaldii. Theor.Appl.Genet. 109(4):865-874 (DOI: 10.1007/s00122-004-1701-1).

Castaño, F., Vear, F. and Tourvieille de Labrouhe, D., 1993. Resistance of sunflowers to different forms of attack by Sclerotinia sclerotiorum and relations with some morphological characters. Euphytica 68: 85-98.

Gulya, T.J., 1996. Changes in sunflower disease incidence in the United states during the last decade. Proc. $14^{\text {th. }}$ Int. Sunflower Conf. Beijing, China 2:651-657.

Huguet, N.I. and Heiland, P., 2000. Analysis of a severe attack of Sclerotinia head rot of sunflower in Argentina. Proc. $16^{\text {th }}$ Int. Sunflower Conf. Toulouse, France 2:I90-I95.

Lamarque, C., 1976. Elements de biologie du Sclerotinia sclerotiorum sur tournesol en France. Information techniques CETIOM 49:21-25.

Liu, L. and Li, X., 1988. The geographical distribution of sunflower diseases in China. Plant Pathology 37:470-474.

Philips, A.J.L.,1989. Fungi associated with sclerotia of Sclerotinia sclerotiorum in South Africa and their effects on the pathogen. Phytophylactica 21:135-139.

Serre, F., Walser, P., Tourvieille de Labrouhe, D. and Vear, F., 2004. Sclerotinia sclerotiorum capitulum resistance tests using ascospores: results over the period 1991-2003. Proc. $16^{\text {th }}$ Int. Sunflower Conf., Fargo, USA 1:129-134.

Tourvieille de Labrouhe, D. and Vear, F., 1984. Comparaison de méthodes d'estimation de la résistance du tournesol à Sclerotinia sclerotiorum (Lib.) de Bary. Agronomie 4:517-525.

Tourvieille de Labrouhe, D., Vear, F. and Habouzit, J., 1986 Culture du tournesol sous tunnel en filet avec humectation contrôlée pour l'étude du Sclerotinia sclerotiorum. Inf. Tech. CETIOM 96:20-28.

Vear, F. and Tourvieille de Labrouhe, D., 1984. Recurrent selection for resistance to Sclerotinia sclerotiorum in sunflowers using artificial infections. Agronomie 4:789-794.

Vear, F. and Tourvieille de Labrouhe, D., 1988. Heredity of resistance to Sclerotinia sclerotiorum in sunflower. II. Study of capitulum resistance to natural and artificial ascospore infections. Agronomie 8:503-508.

Vear, F. and Guillaumin, J.J., 1977. Etude de méthodes d'inoculation du tournesol par Sclerotinia sclerotiorum et application à la sélection. Ann. Amélior. Plantes 27:523-537.

Vear, F. and Tourvieille de Labrouhe, D., 1987. Le jugement des hybrides de tournesol vis-avis de l'infection naturelle des capitules par Sclerotinia sclerotiorum. Inf. Tech. CETIOM 99:9-14. 
Vear, F., Willefert, D., Walser, P., Serre, F. and Tourvieille de Labrouhe, D., 2004. Reaction of sunflower lines to a series of Sclerotinia sclerotiorum isolates. Proc. $16^{\text {th }}$ Int. Sunflower Conf., Fargo, USA 1:135-140.

\title{
MEJORAMIENTO DE UNA POBLACIÓN RESTAURADORA DE LA FERTILIDAD EN GIRASOL POR SU RESISTENCIA A Sclerotinia sclerotiorum EN CAPÍTULOS MEDIANTE SELECCIÓN RECURRENTE.
}

\author{
RESUMEN
}

En una población restauradora de la fertilidad en girasol, creada en el año 1978 , se llevaron a cabo 15 ciclos de selección recurrente por la resistencia a Sclerotinia de capítulos. En los primeros tres ciclos, se utilizó un test que estima la velocidad de crecimiento del micelio del hongo en la superficie dorsal de la inflorescencia; dicho test fue combinado, desde el cuarto ciclo, con otro basado en el asperjado de ascosporas sobre los florones, el cual reproduce con más fidelidad la infección natural. El área enferma en el dorso del capítulo se redujo en un $80 \%$, luego de cuatro ciclos de selecció con el primer test; posteriormente la población permaneció estable y homogénea para este carácter. Se duplicó el período de incubación, obtenido mediante el test con ascosporas, en 12 ciclos de selección y el mejor ajuste con los ciclos de selección se obtuvo mediante una regresión simple con una pendiente significativa, lo que indica que un progreso adicional por selección debería ser aún posible. Los híbridos realizados con la población mejorada luego del primero, sexto y decimoquinto ciclo de selección mostraron una reducción a la mitad del porcentaje de ataque a campo. Asimismo, los híbridos realizados con algunas de las mejores lineas de varios ciclos presentaron aún niveles más altos de resistencia. Esta población se encuentra disponible para mejoradores de girasol y científicos.

\section{AMELIORATION DE LA RESISTANCE DES CAPITULES DE TOURNESOL A Sclerotinia sclerotiorum PAR SELECTION RECURRENTE D'UNE POPULATION RESTAURATRICE DE FERTILITE MALE}

RÉSUMÉ

Quinze cycles de sélection récurrente pour la résistance à la pourriture blanche du capitule due à Sclerotinia ont été effectués sur une population de tournesol restauratrice de fertilité mâle, créée en 1978. Pour les 3 premiers cycles, un test mesurant l'extension de mycélium sur le dos du capitule a été utilisée. À partir du quatrième cycle, il a été combiné avec un test basé sur des infections avec des ascospores qui reproduit plus fidèlement le processus naturel. Avec le premier test, une réduction de $80 \%$ de zone malade a été obtenue pendant les 4 premiers cycles, ensuite ce caractère est resté stable, la population semble être homogène pour ce caractère. Pour le test "ascospores", l'indice de latence (période de latence) à doublé sur les 12 cycles de sélection récurrente, la meilleure relation est obtenue avec une régression simple présentant une pente significative $\left(R^{2}=75,6\right)$, indiquant que d'autres gains de résistance devraient être possibles. Les comparaisons du comportement vis-àvis de la pourriture du capitule des hybrides fabriqués avec les premières, sixièmes et quinzième générations de la population ont montré que ce programme de sélection a permis de réduire de moitié les taux d'attaque observés en infec- 
tion naturelle, certains hybrides présentant un très haut niveau de résistance. Cette population restauratrice de fertilité sélectionnée pour la résistance à la pourriture blanche du capitule est à la disposition des chercheurs et des sélectionneurs du tournesol. 